Russian environmental researcher falls foul of security services

[Moscow] A prominent Russian ecologist has had his passport seized and his laboratory sealed by the country's security services. Confidential reports and classified maps were removed from the Vladivostok apartment and laboratory of Vladimir Soyfer, who has been working on nuclear pollution in the far east of Russia for the last 40 years.

The warrant for the search states: "Since Soyfer's actions pose a threat to the state and military security of the Russian Federation, it seemed necessary to analyse his correspondence." Material confiscated is being studied by military counter-espionage officials. This may lead to Soyfer being charged with revealing state secrets.

Security official Aleksander Kazakov has denied that he knew Soyfer's apartment was being searched, although a check on Soyfer's laboratory had been planned as a routine procedure. The Federal Security Service (FSB) have not confirmed the reports.

Kazakov says that Soyfer was informed of the time of this check, but "he did not wish to be present". But Soyfer denies this, pointing out that he could not be present as he was being treated for diabetes at the Moscow hospital of the Russian Academy of Sciences.

According to the investigation, Soyfer kept secret documents in his laboratory safe that should have been given back to officials, as well as illegal photocopies. The warrant accuses him of negligence under the Russian Criminal Code, although this does not carry a prison sentence.

A letter distributed by Aleksei Yablokov, chairman of the Social-Ecological Union, suggests that the secret services may be trying to prove that Soyfer has passed secret information to foreign agents.

Counter-admiral Nikolai Sotskov, chief of the Pacific Navy's counter-espionage department, denies this. "Neither our navy, nor the FSB, prevent anyone from monitoring the environment," he says.

But Soyfer has had run-ins with the navy before. The author of over 200 scientific articles on radioactive pollution in the region, he has been studying the consequences of a nuclear submarine accident in the bay of Chazhma in 1985, and of radioactive waste dumped in the Japan sea. This led to a confrontation with Pacific Navy commander admiral Mikhail Zakharenko.

"Ecological investigations attract the attention of the special services, because by analysing the structure of pollution it is easy to tell what kind of secret objects - especially nuclear facilities - are nearby," says Nikolay Ponomarev-Stepnoy, vice president of the Kurchatov Institute.

Carl Levitin

\title{
Merger of top Californian medical schools turns sour
}

[SAN FRANCISCO] The merger of hospitals of the University of California at San Francisco (UCSF) and Stanford University, barely two years old, may be dissolved after the disclosure of projected, unexpected losses of at least $\$ 60$ million in the current fiscal year.

The financial situation, which is being blamed on management weaknesses, is so dire that UCSF's faculty leaders last week asked the UC Board of Regents to cancel the hospital partnership.

The merger was designed to meld the clinical operations of the two universities into an academic powerhouse. But it has become a financial nightmare that some officials say is threatening research and teaching.

While faculty members attempt to meet its mission, physicians say they are under such pressure to produce revenue that research is being curtailed, if not eliminated.

"It is time for the regents to exercise their fiduciary responsibility to save the academic mission before it is gutted to save a dysfunctional corporate dream," says Warren Gold, a physician who chairs the UCSF Faculty Association, urging the dissolution of the merger. "The longer you wait before acting, the more difficult it will be to get UCSF back on track."

The regents have decided to support the merger because its goals are too important to let it fail. But the hospital marriage was dealt another blow last week by a legal battle between state authorities and hospital officials. Officials of the hospital corporation, arguing that they were not under state jurisdiction, refused to let the state auditor examine financial records. The auditor then prepared to subpoena the hospital corporation's financial records, while threatening criminal charges against corporate officers who blocked access.

Since the merger, in late 1997, the hospitals - UCSF's facilities in San Francisco and Stanford's in Palo Alto - have been governed by an independent, nonprofit corporation, with a board of UCSF and Stanford representatives.

The auditor and state legislators representing the San Francisco area are concerned about the hospital corporation's growing deficits, including this year's projected $\$ 60$ million loss and estimated losses next year of \$135 million.

University officials attributed the losses to mismanagement of the merger and reductions in government support. Officials at Stanford, a private institution, have been watching the conflict nervously, as the university entered the merger under the agree-

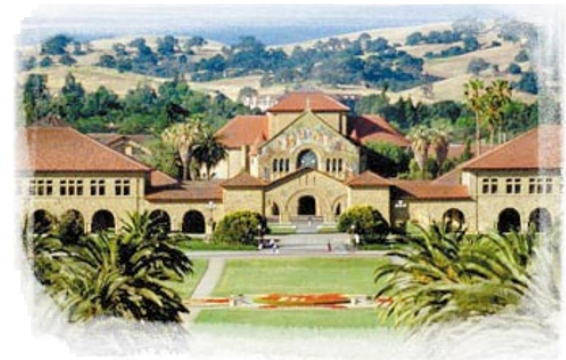

Stanford University: officials are reluctant to open medical-centre accounts to state audit.

ment that the hospital corporation would not disclose financial records.

Last Friday (16 July), a compromise was worked out at a closed-door meeting that would open the hospital corporation's financial records to the state auditor. Had the compromise not been reached, the merger could have been cancelled within weeks.

But the hospital marriage remains under threat, as critics doubt that Stanford will allow a full audit that will satisfy the state. As the compromise was being reached, Eugene D. Bauer, Stanford's vice-president for medical affairs and medical school dean, said that opening the financial books "was a violation of the spirit" of the merger.

At UCSF, the impact of the current situation is most severe for physicians who also work in research - faculty considered crucial to the university's reputation. "This is a tremendous worry," said Svein Oie, a pharmacology researcher who is chairman of the UCSF Medical School's Academic Senate.

"The real problem is with the young people; they find it harder and harder to do research," says Oie. "Unless we can reduce the clinical-care burden on the $\mathrm{MD} / \mathrm{PhD}$ faculty, I don't know if we can resolve the problem."

"For those of us trying to do lab work, it is more and more difficult," said an MD/PhD in the UCSF anaesthesia department, asking not to be named. "Working in the lab is becoming secondary, which will make it harder for academic promotion."

At Stanford, the crisis has prompted some faculty hired for scholarly work to leave, with their positions being filled by clinicians.

"We are in quite a bit of trouble," admits Kenneth L. Melmon, chairman of Stanford Medical School's Academic Senate, a physician and associate dean for postgraduate medical education. "The constitution of the faculty is changing."

At UCSF, the crisis is pitting physicians against basic science researchers. Some basic scientists have even argued that clinical programmes aren't needed — something the physicians contest sharply. RexDalton 